Research Article

\title{
Evaluation of Drinking Water Quality in Rural Area of Amhara Region, Ethiopia: The Case of Mecha District
}

\author{
Mekuanint Lewoyehu \\ Department of Chemistry, College of Sciences, Bahir Dar University, P.O. Box 79, Bahir Dar, Ethiopia \\ Correspondence should be addressed to Mekuanint Lewoyehu; mekle2879@gmail.com
}

Received 26 March 2021; Revised 14 May 2021; Accepted 27 May 2021; Published 10 June 2021

Academic Editor: Zenilda Cardeal

Copyright (c) 2021 Mekuanint Lewoyehu. This is an open access article distributed under the Creative Commons Attribution License, which permits unrestricted use, distribution, and reproduction in any medium, provided the original work is properly cited.

\begin{abstract}
This study was conducted to assess the drinking water quality of north Mecha district, Amhara Region, Ethiopia. 26 drinking water samples were collected from the water points of the dweller community in the dry seasons of 2020 and subjected to the analysis of physicochemical parameters, bacteriological parameters, and the level of trace metals. The analysis of physicochemical parameters and the trace metals was carried out following the standard procedures of the laboratory, and the bacteriological water qualities were measured using the membrane filtration method. The $\mathrm{F}^{-}, \mathrm{NO}^{3-}, \mathrm{SO}_{4}{ }^{2-}$, and $\mathrm{Cu}$ levels of the water samples were within the permissible limits of the WHO and compulsory Ethiopian standard (CES). Depending on turbidity, $61.54 \%$ of the tested water samples crossed the WHO limit of drinking water quality, and $100 \%$ of the samples surpassed the limits of EPA. Based on iron and ammonia levels, $38.46 \%$, and $100 \%$ of the studied water samples violated the environmental protection agency (EPA) guidelines; $23.07 \%$, and $3.84 \%$, of the samples surpassed the WHO and CES drinking water quality standards. In view of pH, $23.07 \%$ of the tested water samples were not within the safe limit of the WHO and CES. $92.31 \%$ of the studied water samples were not potable as coliform bacterium (thermo tolerant indicator bacterium) growth was detected. The study revealed that the water sources of the study area are not safe for drinking unless appropriate treatment measurements are taken. Higher values of water quality parameters for the water samples from Koga irrigation site than the values for the water samples from the study sites found out of the irrigation site indicated the pollution load of Koga irrigation on the water quality of the area.
\end{abstract}

\section{Introduction}

Water is very vital for the endurance of all living organisms. However, it may be a source of several transmission and chronic human disease if it is exposed to bacteriological, chemical, and physical contaminants. Water plays a significant role on the growth of pathogens that have emerged and health problems: an estimation of $80-85 \%$ of the communicable disease is transmitted through water [1]. Rehman et al. [2] stated that the potentially harmful elements contaminations ultimately target the human beings through the intake of contaminated water.

As stated by Boyd [3], public health specialists typically agree that, among the contaminants of drinking water, microbiological pathogens are the foremost, necessary risk exhibit by drinkable water. These pathogens will cause sickness outbreaks that lead to acute health issues for substantial proportions of associate exposed population.

Heavy metals are released into the ecosystem from geogenic (natural alteration of the mineralized zone) and anthropogenic (mining, agrochemicals, and industrial effluents) activities $[4,5]$. Water is a precious and likely the most vulnerable environmental aspect to heavy metals contamination $[6,7]$. Investigations of heavy metals in water help in determining the status and contamination load [8]. Therefore, regular quantification of heavy metals is crucial to identify temporal variations in aquatic ecosystems [9]. Moreover, the nutrients and agrochemicals applied on the cultivation area, adjacent to water bodies, may also reach via overland flows and subsurface flows during precipitation events or at a slower rate reach surface water bodies through groundwater discharge. For example, phosphorus transportation occurs mainly bound to soil particles as overland 
flows, whereas nitrogen can enter aquatic systems via overland flow, subsurface flows, and groundwater flows [10]. On the other hand, population growth and rapid urbanization are increasing pressure on contamination of freshwater resources and cause of poor quality of drinking water. Furthermore, a high level of local water demand are leading to increased water scarcity and stress results in use of nonconventional waters such us untreated or raw wastewater [11].

Water quality is commonly defined by its physical, chemical, biological, and aesthetic (appearance and smell) characteristics. Water quality is closely linked to the surrounding environment and land use. Usually, water could be never pure and may be affected by agriculture, urban, industrial, recreation, and so on. The modification of natural stream flows and the weather or climate change can also have major impact on water quality. Groundwater is a major source of drinking water, and it can be vulnerable to contamination due to agriculture, urban, and industrial development. Microbial or chemical contamination of water cannot be detected by sense organ like sight, smell, or taste. The only way to know if water is contaminated with bacteria or chemicals is to test it in the laboratory. Testing all possible microbial pathogens in water is still very expensive and timeconsuming. Therefore, testing the most common indicators such as total coliform, faecal coliforms, and E. coli bacteria is conducted to detect the quality of water [12].

Living organisms need clean and safe water for their well beings. If the quality of water is compromised, an additional cost is needed for clean drinking water supply [13]. Although access to safe drinking water is a vital agent for human beings, an estimated 1.2 billion people around the world lack access to safe water and close to 2.5 billion are not provided with adequate sanitation [1]. Arnell et al. [14] reported that 1.4-2.1 billion people living in the world are under waterstressed condition. Studies showed that approximately $3.1 \%$ of deaths (1.7 million) and $3.7 \%$ of disability adjusted-lifeyears (DALYs) (54.2 million) worldwide are attributable to unsafe water, poor sanitation, and hygiene [15].

Thus, water quality and the risk to waterborne diseases are critical public health concerns in many developing countries. Close to a billion people, most living in the developing world, do not have access to safe and adequate water [16]. The World Health Organization (WHO) estimated that around $94 \%$ of the global diarrheal burden and $10 \%$ of the total disease burden are due to unsafe drinking water, inadequate sanitation, and poor hygienic practices [17]. Clean drinking water provision in developing countries like Pakistan is difficult due low-income level, awareness, and high population growth. The potentially harmful elements contamination in water and sediment has been reported from various parts of Pakistan by Rehman et al. [2] and surroundings by Nasirian et al. [18]. Recently, heavy metal contamination in water and fish has been studied at various locations [19], including southern Pakistan [20].

According to the reported literatures [21], the quantity of available water in developing regions of Africa, Middle East, and South Asia is decreasing sharply, while quality of water is deteriorating rapidly due to fast urbanization, deforestation, and land degradation. In Africa, roughly $40 \%$ of the population does not have access to improved water supply and sanitation [22]. Study conducted in rural villages of Mohale Basin in Lesotho shows that drinking water was polluted by Escherichia coli (78\% of unprotected water and $60 \%$ of protected water sources), and $59 \%$ of water sample contains open defecation with poor control of hygiene practice [23].

Unfortunately, in developing countries like Ethiopia, the drinking quality of water is continuously being contaminated and hazardous for human use due to high growth of population, expansion in industries, and throwing away of wastewater and chemical effluents into canals and other water sources. In Ethiopia, studies conducted in Dire Dawa and Jimma revealed $83.34 \%$ and $87.5 \%$ of water sample were positive for bacterial indicators, respectively [24]. Additionally, a study conducted in North Gondar showed that springs $(35.7 \%)$, protected wells $(28.6 \%)$, and water lines (50\%) had Escherichia coli [25].

In many parts of the country, rural residents use borehole or spring water for their domestic and drinking consumption without strict water quality monitoring $[26,27]$. Groundwater projects are hardly supervised by trained groundwater professionals [28]. Like many developing regions, there exist few data for the general state of groundwater quality across Ethiopia $[29,30]$. In this study, the concern is the water quality of hand-dug well, shallow well, and developed spring waters at Mecha district, $500 \mathrm{~km}$ far from Addis Ababa (the capital of Ethiopia), found in West Gojjam zones of Amhara National Regional State.

The current study was conducted in four selected kebeles of North Mecha district: Midre Genet, Felege Birhan (found out of Koga irrigation), Inguti, and Kudmi (found in Koga irrigation). In a community of north Mecha district, Inguti and Kudmi kebeles, only $68.25 \%$ of the population (from the total population of 18,984 ) obtained drinking water from the protected areas, while the remaining $31.75 \%$ of the population use unprotected and river water sources including the dam canals of Koga irrigation. There are 37 different types of water points in the two kebeles. These are deep well, developed spring, and shallow well. Agrochemicals and fertilizers used by farmers in Koga irrigation site go off to the water points which the dweller communities use as their drinking water sources. Hence, the constructed community water providers are suspected to be contaminated as a result of agrochemicals and anthropological interventions in the area. To handle such problems, it is necessary to carry out water quality assessment, planning, and management. However, no attention was paid to the most sensitive and vulnerable compartment of ecosystem, i.e., the water quality of the area. Therefore, the aim of this study was to assess the quality of water from the indicated sources by comparing with the national and international standards, through the analysis of the physicochemical, biological parameters, and trace metal levels of the water samples. For comparison, drinking water samples were collected from Midre Genet and Felege Birhan kebeles found out of the irrigation project. This helps to determine the potability of drinking water in this area. It can also indicate the impacts of Koga irrigation 
agriculture activities on the physicochemical and biological quality of drinking water in the area.

\section{Materials and Methods}

2.1. Description of the Study Area. The study was conducted in Mecha district, Amhara National Regional State, Ethiopia (Figure 1), in the dry seasons of 2020. Mecha district is situated at $500 \mathrm{~km}$ northwest of Addis Ababa, the capital of Ethiopia, and $35 \mathrm{~km}$ to the west of Bahir Dar, the capital of Amhara region. The total population of Mecha district is 375,716: 323,315 in rural areas and 52401 in urban areas. The study area lies between the coordinates $10^{\circ} 24^{\prime} 62^{\prime \prime} \mathrm{N}$ latitude and $37^{\circ} 08^{\prime} 97^{\prime \prime} \mathrm{E}$ longitudes and has an area coverage of 156 $027 \mathrm{ha}$. It is also situated at an elevation ranging from 1795 to 3268 meter above the sea level [31].

As a result of this elevation difference, variables such as climate, vegetation, and soils show a discrepancy. The study area exhibit two major traditional climatic zones: the Dega (2300-3200 MASL) and Woyna Dega (1500-2300) MASL with mean annual rainfall of 1500-2200 mm [31, 32]. Woyna Dega climatic area has a cool to warm semihumid weather, with average annual temperatures greater than $20^{\circ} \mathrm{C}$. The Dega area has a cool and humid climate with a mean annual temperature ranging from $10^{\circ} \mathrm{C}$ to $20^{\circ} \mathrm{C}$ [33]. Frequent flooding and severe erosion are major problems in the area, especially in the upper stream. In the study area, erosion rate as high as $1.66 \mathrm{Mg} \mathrm{km}^{-2} \mathrm{yr}^{-1}$ is reported [34].

Mecha district is a foundation for Koga watershed which is located in Tana subbasin, Eastern part of the Blue Nile. The rivers draining Koga watershed begin from Mount Wezem and flow into Gilgel Abay, which finally drains into Lake Tana. The high runoff and associated sediment flow from the upper part of this watershed and have serious consequences on the downstream users and water bodies (e.g., Lake Tana and reservoirs developed for irrigation). The watershed exhibits an elevation range of 1890-3200 meter above the sea level [33].

In response to increasing demand for food and contrastingly declining agricultural production in the study area, the Ethiopian government constructed Koga dam in Koga watershed to irrigate 7,000 ha land. The Koga irrigation project is found between 1892 and 2043 masl altitude with UTM coordinates of $\mathrm{N} \mathrm{1,255,000,} \mathrm{N} \mathrm{1,270,000,} \mathrm{E} \mathrm{290,000,}$ and $\mathrm{E} 300,000$. The project area covers a total size of about 10,000 ha [34].

Land use of the study area is dominated by traditional subsistence peasant farming on individual holdings [35]. Agriculture is the mainstay of livelihood in the study area. Crop and livestock production are fully integrated, and thus, the production system can be referred to as a mixed farming system. Traditionally, rain-fed production of cereals dominated by barley, wheat, teff, millet, noug, and maize are the chief crops in this area. In the study area, livestock plays an increasingly important role in the household budget. Crop residue and extensive grazing in the low-lying areas are the major contributors to livestock feed resource. Livestock provides meat, milk, and energy. Manure fulfils an important role through nutrient cycling between and within farms, which enables the continued use of smallholder

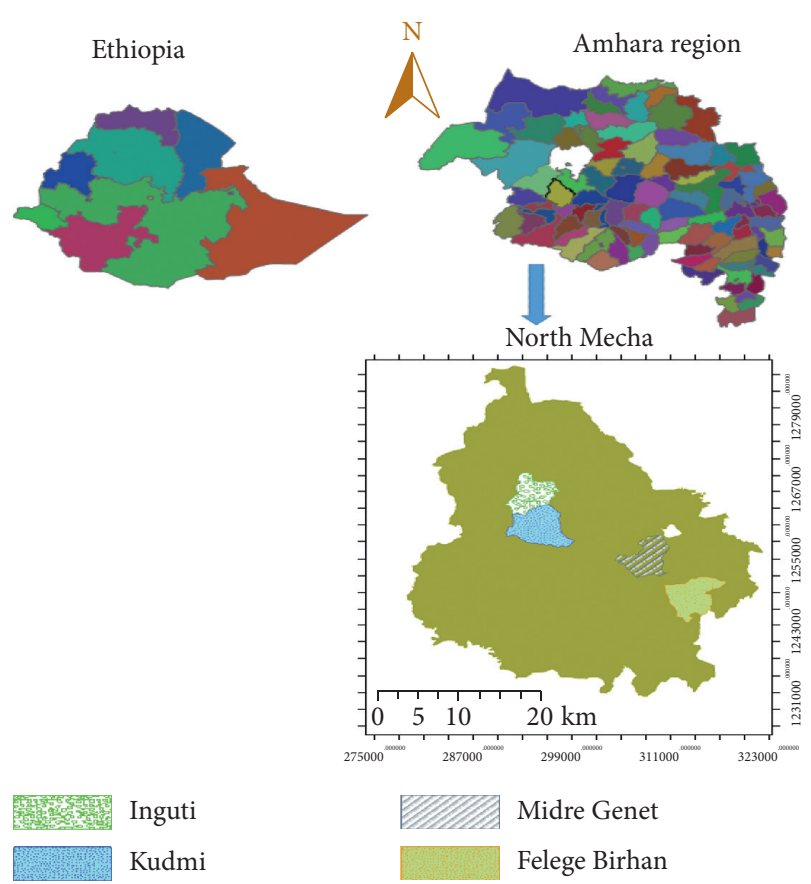

FIGURE 1: Location map of the study areas.

farms. Farmers usually have cattle, sheep, goat, mule, and donkey [35].

2.2. Sampling Procedures. This study was a cross-sectional study to find out the physicochemical and bacteriological quality of drinking water sources found in Midre Genet, Felege Birhan (non-irrigated areas), and Inguti and Kudmi kebeles of agriculture irrigated areas. Prior to their use, all sampling materials including sample holders were washed with detergent, rinsed with distilled water, soaked with $10 \%$ $\mathrm{HNO}_{3}$ for $24 \mathrm{hr}$, rerinsed with deionized water, and finally air dried [36].

From different water sources of the dwellers, 26 water samples (twelve from deep well, eight from a shallow well, and six from protected spring) were collected. To estimate the effects of Koga irrigation on the drinking water quality of the area, 14 of the water samples (SW1-SW5, DW1-DW6, and DS1-DS3) were collected from Inguti and Kudmi kebeles which are found within the Koga irrigation project. For comparison, the remaining water samples (SW6-SW8, DW7DW12, and DS4-DS6) were collected from Midre Genet and Felege Birhan kebeles found out of the irrigation project. Water samples were collected from three different points of each site using prerinsed $250 \mathrm{ml}$ polyethylene bottles. Some physicochemical parameters of water samples were measured at the site, and samples from the three points of each site mixed in a one-liter polyethylene container to which $2 \mathrm{ml}$ nitric acid was added to reduce adsorption of metals on to the walls of the plastic bottles. Sample bottles were then labeled for date of sampling and sampling site [37]. Samples were transported in an ice box to the laboratory and stored at $4^{\circ} \mathrm{C}$ until further treatment. All the samples were maintained in the freezer and kept refrigerated until needed for chemical analyses. 
2.3. Equipment and Chemicals. The $\mathrm{pH}$ meter (JENWAY model 370), EC meter (HANNA model Hi9033 multirange conductivity meter), hotplate, volumetric flask $(100,150 \mathrm{ml})$, filter paper (Whatman no. 1), spectrophotometer (Model DR 7100, Japan), dropper (LDPE 0.5-1 ml), sample cells (1 inch square, $10 \mathrm{ml}$ ), turbidometer (nephelometric), sample bottle, hand lens vacuum pump, Palintest Nitratest Tube (PT526, $20 \mathrm{ml}$ ), and Palintest photometer (https://www. palintest.com) were used in the research.

Nitric acid (69-72\%), hydrogen peroxide (30\%), hydrochloric acid (37\%), lanthanium nitrate, calcium chloride (anhydrous), Palintest phosphate, HR tablets, SR tablets, deionized water (in $2 \% \mathrm{HNO}_{3}$ ), sulfuric acid (98\%), ferric chloride (hexahydrated), buffer solutions (pH: 4.7 and 7.01), distilled water, NitraVer 5 nitrate reagent powder Pillow, SPADNS reagent, ammonia salicylate reagent powder, Ammonia cyanurate reagent powder Pillow, PhosVer 3 phosphate reagent powder Pillow, FerroVer iron reagent powder Pillow, CuVer 3 cupper reagent powder Pillow, SulfaVer 4 sulfate reagent powder Pillow, and Lauryl sulfate broth were among the analytical grade chemicals used in the research.

2.4. Analysis of Physicochemical and Biological Parameters. The measurement of physicochemical parameters such as temperature, electrical conductivity, TDS, turbidity, and $\mathrm{pH}$ were carried out directly at the sampling sites using a portable conductivity meter, turbidometer, and $\mathrm{pH}$ meter.

The $\mathrm{pH}$ measurements were done after calibration of the $\mathrm{pH}$ electrode with buffer solutions. For electrical conductivity measurement, the EC electrode was calibrated using a standard solution of $\mathrm{KCl}$ after which the sample was taken from the source using a $100 \mathrm{ml}$ plastic container and direct measurements were done. In situ measurement of turbidity was done using a turbidometer (nephelometric). Before analysis, prepared standards were used to calibrate the turbidometer in the desired range of accuracy using manufacturer's operating instruction. $10 \mathrm{ml}$ water sample was taken in cuvettes, and readings were taken in nephelometric turbidity units (NTU).

The nitrate, fluoride, ammonia, sulfate, phosphate, iron, and copper levels $(\mathrm{mg} / \mathrm{l})$ were determined using a spectrophotometer adjusted at different wave lengths. Nitrate was analyzed by the DR 2010 spectrophotometer instrument. For nitrate, the spectrophotometer was adjusted at $355 \mathrm{~nm}$ after which a square sample cell was filled with $10 \mathrm{ml}$ of water sample, and one NitraVer 5 nitrate reagent powder Pillow was added, swirled, and waited until the reaction took place. Finally, the prepared sample was inserted into the cell holder, and absorbance of the solution was measured.

For fluoride $\left(\mathrm{F}^{-}\right)$, the spectrophotometer was adjusted at $190 \mathrm{~nm}$, and $2.0 \mathrm{ml}$ of SPANDS reagent was added to a square sample cell filled with $10 \mathrm{ml}$ water. It was left for the reaction to take place, and absorbance was measured after the completion of the reaction. Similarly, ammonia, phosphate, sulfate, copper, and iron levels were determined by adjusting the spectrophotometer at $343 \mathrm{~nm}, 490 \mathrm{~nm}, 680 \mathrm{~nm}$, $135 \mathrm{~nm}$, and $265 \mathrm{~nm}$, respectively. Ammonia salicylate reagent, PhosVer 3 phosphate reagent, SulfaVer 4 sulfate reagent, $\mathrm{CuVer} 3$ copper reagents, and FerroVer iron reagent were the respective reagents used for the analysis. All the parameters were analyzed as described in standard methods.

Bacteriological analyses of water samples were done according to the procedure given by the WHO [38]. Membrane filter technique was used since the method is more rapid, quantitative results in or presumptive positive about 18 hours, less labour-intensive, requires less culture medium, requires less glassware, and results obtained directly by colony count (high precision) [39]. The membrane filter apparatus sterilized with a flame from a gas burner and swiped with an alcohol soaked cotton wool was used. This method was used to directly count the thermotolerant colony present in a given water sample. $100 \mathrm{ml}$ of water was filtered out, under vacuum, through membrane filter apparatus with a uniform pore diameter of $0.45 \mu \mathrm{m}$. Bacteria retained on the surface of the grid filter paper was placed on a suitable prepared medium (Lauryl sulfate broth in a sterile Petri dish) and incubated at an appropriate temperature of $44.5^{\circ} \mathrm{C}$ for 24 hours. The thermotolerant or faecal coliforms in the water samples grown into yellow colonies were directly counted. A hand lens was also used to count the colonies which were invisible to our naked eyes.

\section{Results and Discussion}

3.1. Physicochemical Characteristics of the Water Samples. The level of some physicochemical parameters of the analyzed water samples are given in Tables 1 and 2 .

3.1.1. Temperature. Temperature measurements are very useful in understanding the trend of physical, chemical, and biological activities which are enhanced/retarded by the variation of temperature. In the present study, the temperature of the water samples varied from 15.0 to $25.6^{\circ} \mathrm{C}$ (Table 1). This is beyond the WHO standard of $<15^{\circ} \mathrm{C}[40]$. The higher temperature variability might be due to the current change in the climatic condition of the area. This may enhance the growth of bacteria and increase the water test. Simon [41] reported the maximum temperature of $24.2^{\circ} \mathrm{C}$ for the hand-dug well drinking water in the Koga irrigation area, while Åsa and Kristin [42] reported $22.2^{\circ} \mathrm{C}$ for the same drinking water well.

3.1.2. Turbidity. The control of turbidity is one of the indicators of the efficiency of treatment at the plant. The scattering of light increases as the presence of suspended load increases, and turbidity is commonly measured in nephelometric turbidity units (NTU). Elevated levels of turbidity in the treated water indicate that the treatment process is not operating adequately. It also provides a good indication of whether the treatment plant is capable of removing Cryptosporidium oocysts. While the parametric value for turbidity (at the tap) is that the water must be "acceptable to consumers and (there must be) no abnormal change," there is a parametric value for turbidity (for water leaving the treatment plant) of $1.0 \mathrm{NTU}$. However, it must be 
TABLE 1: Level of simple physicochemical parameters of the analyzed water samples of the sampling sites.

\begin{tabular}{|c|c|c|c|c|c|}
\hline S.P. & $T\left({ }^{\circ} \mathrm{C}\right)$ & Turbidity (NTU) & $\mathrm{pH}$ & TDS (mg/l) & $\mathrm{EC}(\mu \mathrm{s} / \mathrm{cm})$ \\
\hline SW1 & 16.2 & 3.2 & 8.5 & 82 & 165 \\
\hline SW2 & 20.1 & 5.0 & 6.5 & 37 & 74 \\
\hline SW3 & 19.6 & 5.6 & 6.8 & 65 & 129 \\
\hline SW4 & 19.0 & 5.0 & 8.4 & 83 & 164 \\
\hline SW5 & 15.9 & 4.0 & 6.85 & 70 & 140 \\
\hline SW6 & 16.0 & 2.8 & 8.1 & 71 & 135 \\
\hline SW7 & 18.5 & 4.0 & 6.8 & 26 & 54 \\
\hline SW8 & 15.0 & 4.3 & 8.2 & 53 & 101 \\
\hline DW1 & 25.6 & 34.0 & 7.46 & 129 & 257 \\
\hline DW2 & 22.3 & 12.0 & 7.01 & 152 & 304 \\
\hline DW3 & 20.8 & 8.0 & 6.3 & 64 & 127 \\
\hline DW4 & 21.1 & 9.4 & 5.89 & 22 & 44 \\
\hline DW5 & 19.1 & 4.5 & 6.0 & 26 & 54 \\
\hline DW6 & 21.0 & 7.8 & 5.9 & 34 & 67 \\
\hline DW7 & 22.0 & 22.0 & 7.5 & 100 & 201 \\
\hline DW8 & 20.3 & 8.0 & 7.22 & 115 & 253 \\
\hline DW9 & 20.0 & 6.0 & 6.8 & 40 & 100 \\
\hline DW10 & 18.7 & 7.4 & 6.91 & 11 & 34 \\
\hline DW11 & 18.0 & 3.5 & 6.88 & 15 & 43 \\
\hline DW12 & 18.1 & 6.5 & 7.45 & 44 & 51 \\
\hline DS1 & 18.7 & 6.7 & 6.03 & 28 & 56 \\
\hline DS2 & 18.1 & 5.5 & 6.6 & 69 & 139 \\
\hline DS3 & 19.5 & 2.45 & 6.1 & 26 & 51 \\
\hline DS4 & 18.0 & 5.5 & 7.2 & 14 & 45 \\
\hline DS5 & 19.1 & 4.5 & 7.4 & 44 & 109 \\
\hline DS6 & 18.2 & 1.55 & 7.0 & 14 & 41 \\
\hline
\end{tabular}

S.P., sampling points; SW, shallow well; DW, deep well; DS, developed springs.

TABLE 2: Level of some chemical parameters of the analyzed water samples of the sampling sites.

\begin{tabular}{|c|c|c|c|c|c|}
\hline S.P. & Nitrate $(\mathrm{mg} / \mathrm{l})$ & Fluoride $(\mathrm{mg} / \mathrm{l})$ & Ammonia (mg/l) & $\mathrm{SO}_{4}{ }^{-2}(\mathrm{mg} / \mathrm{l})$ & $\mathrm{PO}_{4}^{-3}(\mathrm{mg} / \mathrm{l})$ \\
\hline SW1 & 7.6 & 0.1 & 0.8 & 3.0 & 0.32 \\
\hline SW2 & 4.8 & 0.01 & 1.3 & 12.0 & 2.3 \\
\hline SW3 & 6.7 & 0.01 & 0.46 & 8.0 & 0.43 \\
\hline SW4 & 5.9 & 0.01 & 0.54 & 9.0 & 0.4 \\
\hline SW5 & 4.9 & 0.01 & 0.53 & 11.0 & 0.34 \\
\hline SW6 & 4.61 & 0.009 & 0.38 & 4.5 & 0.14 \\
\hline SW7 & 3.6 & 0.098 & 0.4 & 2.1 & 0.12 \\
\hline SW8 & 3.9 & 0.007 & 0.8 & 6.5 & 1.1 \\
\hline DW1 & 17.8 & 0.01 & 0.9 & 5.0 & 1.2 \\
\hline DW2 & 27.8 & 0.002 & 1.4 & 15.0 & 1.1 \\
\hline DW3 & 19.2 & 0.01 & 1.4 & 10.0 & 0.9 \\
\hline DW4 & 26.7 & 0.01 & 1.2 & 11.0 & 1.1 \\
\hline DW5 & 24.5 & 0.012 & 0.9 & 12.0 & 1.2 \\
\hline DW6 & 31.7 & 0.011 & 2.4 & ND & 1.31 \\
\hline DW7 & 10.0 & 0.0079 & 0.5 & 4.6 & 0.14 \\
\hline DW8 & 12.0 & 0.0071 & 0.82 & 3.0 & 0.6 \\
\hline DW9 & 10.5 & 0.0072 & 0.80 & 8.0 & 0.51 \\
\hline DW10 & 11.2 & 0.0069 & 0.6 & 7.0 & 0.38 \\
\hline DW11 & 11.0 & 0.0099 & 0.51 & 7.5 & 0.5 \\
\hline DW12 & 15.7 & 0.0089 & 1.5 & 7.1 & 0.5 \\
\hline DS1 & 19.7 & 0.01 & 1.2 & 5.0 & 1.6 \\
\hline DS2 & 20.6 & 0.02 & 1.1 & 8.0 & 1.8 \\
\hline DS3 & 23.4 & 0.012 & 1.5 & 3.0 & 1.3 \\
\hline DS4 & 10.7 & 0.0017 & 0.55 & 4.0 & 1.0 \\
\hline DS5 & 11.0 & 0.0091 & 0.5 & 5.0 & 1.12 \\
\hline DS6 & 11.2 & 0.0099 & 0.85 & 2.2 & 0.91 \\
\hline
\end{tabular}


stressed that this value is for visual acceptability of the water. In practice, turbidity levels need to be much lower and should not exceed 0.2 NTU and preferably be below 0.1 NTU to be protective against Cryptosporidium breakthrough in the treatment plant [43]. Comparing the turbidity results of the current study with the given standards of EPA, $100 \%$ of the samples crossed the maximum limits of turbidity. According to the WHO standards for drinking water, the high desirable level of turbidity is $0.00 \mathrm{NTU}$ and high permissible level is 5 NTU [44]. Based on these standards, $61.54 \%$ of the analyzed water samples (SW2-SW4, DW1DW4, DW6-DW10, DW12, DS1-S2, and DS4) (Table 1) were found to have turbidity values above the recommended limits. Meseret [45] analyzed the water quality of Simada district, Ethiopia, and reported the turbidity values in the range $0.7-46 \mathrm{NTU}$, and $29 \%$ of the analyzed samples were found to have turbidity values above the water quality standards. In the study by Gurmessa [46] where he reported the water quality of Oromia region, Ethiopia, $83.3 \%$ of the tested samples were not good fit for drinking based on turbidity. Worako [30] reported the turbidity value between 6.82 and 20.98 NTU for Lake Hawassa. Simon [41] reported the turbidity level of 6.5 for the drinking water from the well found in Koga irrigation; this was a little higher than the drinking water limit of 5 NTU suggested by the WHO.

3.1.3. $p H$. The $\mathrm{pH}$ which depends on carbon dioxide and carbonate-bicarbonate equilibrium is an important indicator of water quality. The $\mathrm{pH}$ is an important variable in water quality assessment as it influences many biological and chemical processes within a water body and all processes associated with water supply and treatment. Dial variations in $\mathrm{pH}$ can be caused by the photosynthesis and respiration cycles of algae in eutrophic waters. The $\mathrm{pH}$ of most natural waters is between 6.0 and 8.5, although lower values can occur in dilute waters high in organic content and higher values in eutrophic waters, ground water brines, and salt lakes [47]. The WHO has recommended permissible limit of $\mathrm{pH}$ from 6.5 to 8.5 . The $\mathrm{pH}$ values of the current water samples ranged 5.89-8.5. Based on the results, $23.07 \%$ of the analyzed water samples were not within the safe limit of standard set by the WHO and Ethiopian drinking water guidelines. Simon [41] reported $\mathrm{pH}$ around 7.3-7.4 for the drinking groundwater well in Koga irrigation.

3.1.4. Total Dissolved Solids. In drinking water, total dissolved solids are primarily made up of inorganic salts with small concentrations of organic matter. Contributory ions are mainly carbonate, bicarbonate, chloride, sulfate, nitrate, potassium, calcium, and magnesium. A major contribution to total dissolved solids in water is due to the natural contact with rocks and soil. Total dissolved solids in drinking water originated from natural sources, sewage, urban runoff, and industrial wastewater [38]. Talling [48] stated that the primary sources of TDS are the agricultural and residential runoff, leaching of soil contamination. As given in Table 1, total dissolved solids concentration in this study ranged 11-152 mg/l. According to the WHO standards [49], the highest desirable and highest permissible level for total dissolved solids are $500 \mathrm{mg} / \mathrm{l}$ and $1000 \mathrm{mg} / \mathrm{l}$, respectively. Accordingly, total dissolved solids value for all samples in the studied area lied within desirable range for drinking purposes. Thus, the low TDS level of the water from the specific sites indicated the circumstance of using the water for drinking and other domestic purposes.

3.1.5. Electrical Conductivity. Electrical conductivity in water is the measurement of the ability of a solution to carry an electrical current. This ability depends on the presence of ions, their total concentrations, mobility, and on the temperature of measurements [50]. Conductivity is an important factor in water quality measurement because it gives a good idea of the amount of dissolved materials in water [51]. Electrical conductivity value in the present investigation ranged between 34 and $304 \mu \mathrm{s} / \mathrm{cm}$ (Table 1). The maximum acceptable level of conductivity as indicated by USEPA [52] is $1000 \mu \mathrm{s} / \mathrm{cm}$. The WHO limits conductivity in the range $400-1200 \mu \mathrm{s} / \mathrm{cm}$. In view of that, the EC values of all studied samples lied within permissible range for drinking purposes. These values are lower than the EC values reported by Meseret [45] $(496 \mu \mathrm{s} / \mathrm{cm})$ and Gebreyesus [53] $(3700 \mu \mathrm{s} / \mathrm{cm})$. Based on Richard's classification of water for irrigation use based on the EC value [54], the water samples SW1, SW2, SW3, SW4, SW5, SW6, SW8, DW3, DW4, DW5, DW6, DW7, DS1, DS2, DS3, and DS5 were classified as excellent (EC $(\mu \mathrm{S} / \mathrm{cm}): 100-250)$, while samples DW1, DW2, and DW8 were good (EC $(\mu \mathrm{S} / \mathrm{cm}): 250-750)$ (Table 1). Simon [41] reported $422 \mu \mathrm{S} / \mathrm{cm}$ conductivity of the drinking groundwater well in Koga.

3.1.6. Fluoride. Fluoride concentrations of $0.7-1.2 \mathrm{mg} / \mathrm{l}$ in drinking water will protect against dental cavities. However, excessive levels (more than $1.5 \mathrm{mg} / \mathrm{l}$ ) may cause discoloration or mottling of the teeth. This occurs only in developing teeth before they push through. Elevated fluoride levels also may cause skeletal damage and bone disease. Because low levels of fluoride are common in groundwater, most municipalities add fluoride to the water. The fluoride contents of the water samples in the current study were in the range $0.0017 \mathrm{mg} / \mathrm{l}$ (DS4) to $0.1 \mathrm{mg} / \mathrm{l}$ (SW1) (Table 2). Based on the WHO and Ethiopian drinking water quality standards, the fluoride content of all analyzed water samples were within the permissible limits. The fluorides results were lower than the fluorides contents reported earlier by Gurmessa [46] (0.05-0.27 mg/l) and Gebreyesus [53] (0.9-2.6 mg/l). Fluoride arises almost exclusively from fluoridation of public water supplies and from industrial discharges, although it occurs naturally in quite rare instances. Past health studies have shown that the addition of fluoride to water supplies at levels above $0.6 \mathrm{mg} / \mathrm{l} \mathrm{F}^{-}$leads to a reduction in tooth decay in growing children and that the optimum beneficial effects were thought to occur around $1.0 \mathrm{mg} / \mathrm{l}$. However, in light of recent international and Irish research which shows an increasing occurrence of dental fluorosis, the Forum on Fluoridation (2002) recommended the lowering of the fluoride levels in drinking water to a range of $0.6-0.8 \mathrm{mg} / \mathrm{l}$, 
with a target of $0.7 \mathrm{mg} / \mathrm{l}$. In the study by Åsa and Kristin [42], the measured value of fluoride for the drinking water well in Koga was $161.019 \mathrm{ppb}$, which is below the minimum guideline value $(0.5 \mathrm{mg} / \mathrm{l})$. Worako [30] reported concentration of $\mathrm{F}^{-}$for Lake Hawassa ranged 2.31-17.29 mg/l with an average value of $12.83 \mathrm{mg} / \mathrm{l}$, which is far apart from the WHO $(1.5 \mathrm{mg} / \mathrm{l})$ and EEPA $(3.0 \mathrm{mg} / \mathrm{l})$ recommended limit of $\mathrm{F}^{-}$concentration for the drinking water.

3.1.7. Nitrate Concentration. Nitrate is a compound of nitrogen and oxygen that is found in many ways. The groundwater has high nitrate concentration than surface water because of the percolating sewage, industrial waste, chemical fertilizers, leaches from solid waste landfills, and septic tank effluents to the groundwater. The nitrate concentration in surface and groundwater is normally low but can reach high levels as a result of leaching or runoff from agricultural land or contamination from human and animal wastes [38]. Nitrate in the environment originates mostly from organic and inorganic sources such as waste discharges, animal slurries, and artificial fertilizer. High levels of nitrate in drinking water may induce "blue baby" syndrome (methemoglobinemia). The nitrate converts to nitrite which reacts with blood hemoglobin, thus reducing the availability of the blood to hold oxygen [43]. Nitrate concentration in the studied samples ranged $3.6-31.7 \mathrm{mg} / \mathrm{l}$ (Table 2), which is below the maximum permissible limit of nitrate $(50 \mathrm{mg} / \mathrm{l})$ as stated by Compulsory Ethiopian Standard (CES) [55] and WHO. This revealed that water in the study area is safe in terms of the $\mathrm{NO}_{3}{ }^{-}$content for drinking and other domestic uses. However, the nitrate content of most of the studied water samples were above the nitrate concentration reported earlier by Mesert [45] (3-12.76 mg/l) and Gebreyesus [53] (1.33-3.42 mg/l). This may be due to the chemical fertilizers used in Koga irrigation site.

3.1.8. Sulfate. Sulfate is an abundant ion in the earth crust, and its concentration in water range from few to several milligrams per liter [56]. Sulfate occurs naturally in groundwater in numerous minerals including barite $\left(\mathrm{BaSO}_{4}\right)$, episomite $\left(\mathrm{MgSO}_{4} \cdot 7 \mathrm{H}_{2} \mathrm{O}\right)$, and gypsum $\left(\mathrm{CaSO}_{4} \cdot 2 \mathrm{H}_{2} \mathrm{O}\right)$ [40]. Sulfates are naturally occurring anions found almost in all types of water. According to the WHO [12] guidelines for drinking water quality, $\mathrm{SO}_{4}{ }^{2-}$ should be $250 \mathrm{mg} / \mathrm{l}$ as a threshold level. In the current study, the maximum sulfate concentration of the studied samples was $15 \mathrm{mg} / \mathrm{l}$, which is higher than the maximum sulfate concentration reported by Âsa and Kristin [42] $(3.374 \mathrm{mg} / \mathrm{l})$ for the drinking water well in Koga. In the present study, none of the samples had values greater than the recommended level. According to USEPA [52], the allowable concentration must be lower than $250 \mathrm{mg} / \mathrm{l}$; accordingly, the sulfate content of the studied water samples was within the suitable standard for drinking purposes.

3.1.9. Phosphate. Phosphates in water mostly originated from sewage effluents, which contain phosphate-based synthetic detergents, from industrial effluents or from land runoff where inorganic fertilizers have been used in farming. Phosphate is a major source of concern for surface waters because small amounts may lead to eutrophication of lakes and rivers. Historically, phosphate was not considered to be a significant problem in groundwater because it is not very mobile in soils or sediments and should therefore be retained in the soil zone. However, in extremely vulnerable areas, where the soil and subsoil are shallow and where phosphate enters groundwater in significant quantities, it may act as an additional nutrient enrichment pathway for receptors such as lakes, rivers, and wetlands. The maximum allowed concentration for phosphorus in drinking water is $5 \mathrm{mg} / \mathrm{l}$ as $\mathrm{P}_{2} \mathrm{O}_{5}$, equivalent to $2.2 \mathrm{mg} / \mathrm{l} \mathrm{P}$ (SI No. 81 of 1988). This is well above natural levels and an annual median phosphate concentration of $0.03 \mathrm{mg} / \mathrm{l} \mathrm{P}$ is cited as a limit (to prevent eutrophication in surface waters) in phosphate regulations [57]. This may be taken as a threshold value for groundwater that contributes a large proportion of the flow in receiving surface waters. In this study, the phosphate concentration ranged $0.12-2.3 \mathrm{mg} / \mathrm{l}$ which is above the phosphate regulations limit of EPA. Simon [41] reported phosphate concentration in the range $0.5-0.6 \mathrm{mg} / \mathrm{l}$ for the drinking water in Koga irrigation. The higher phosphate content of the drinking water samples in this study revealed the pollution load of Koga irrigation project on the water quality of the area.

USEPA makes the following recommendations [58]: (1) total $\mathrm{PO}_{4}-\mathrm{P} \leq 0.05 \mathrm{mg} / \mathrm{l}$ in a stream at a point where it discharges into a lake or reservoirs, (2) total $\mathrm{PO}_{4}-\mathrm{P} \leq 0.1 \mathrm{mg} /$ 1 in streams that do not discharge directly into lakes or reservoirs, and (3) total $\mathrm{PO}_{4}-\mathrm{P} \leq 0.025 \mathrm{mg} / \mathrm{l}$ for reservoirs. In view of these recommendations, the phosphate concentration of the water samples from all sampling sites crossed the recommended limits. The Swaziland Water Services Corporation (SWSC) recommends a $\mathrm{PO}_{4}-\mathrm{P}$ (total) of $\leq 1.0 \mathrm{mg} / \mathrm{l}$ for drinking water. Based on this recommendation, the phosphate concentrations of the samples SW2, SW8, DW1, DW2, DW4, DW5, DW6, DS1, DS2, DS3, and DS5 were above the limit. The remaining water samples satisfied the SWSC standard/MCL of $1.0 \mathrm{mg} / 1 \mathrm{PO}_{4}$-P for drinking water as well as the South African Standard of $1 \mathrm{mg} / 1 \mathrm{PO}_{4}-\mathrm{P}$ for sewage effluent being discharged into receiving waters.

3.1.10. Ammonia. Ammonium in water supplies originates from agricultural and industrial processes, as well as from disinfection with chloramines (a method of disinfection not in use in Ireland). Elevated levels of ammonium may arise from intensive agriculture in the catchment of the water source. Ammonium is therefore an indicator of possible bacterial, sewage, and animal waste pollution. Ammonium in itself is not a health risk, but the parametric value serves as a valuable indicator of source pollution. The parametric value of ammonium as stated by EPA is $0.3 \mathrm{mg} / \mathrm{l}$, and its permissible limit recommended by the WHO and CES is $1.5 \mathrm{mg} / \mathrm{l}$. The level of ammonia in the water samples of the current study varied from $0.38-2.4 \mathrm{mg} / \mathrm{l}$. While the ammonia level of $100 \%$ of the studied samples violated the guideline set by EPA, only one sample (DW6) crossed the 
WHO and CES guideline of drinking water quality. The ammonia level of the water samples from the kebeles in Koga irrigation is higher than the ammonia level of the samples from the study sites out of the irrigation site. This relatively higher ammonia content of the water samples may be due to agriculture fertilizers used in Koga irrigation found near the area. High levels of ammonia are usually due to agricultural, sewage, and metabolic processes in the ground [59]. Simon [41] reported the ammonia level of $0.1-0.12 \mathrm{mg} / \mathrm{l}$ for the drinking water from the groundwater well in Koga.

3.2. Trace Metal Characteristics of the Water Samples. To estimate the level of trace metals, the copper and iron levels of drinking water samples from the study area were measured (Table 3).

3.2.1. Copper. Copper is a nutrient essential for health, though at elevated levels can become a contaminant (elevated levels can cause acute gastrointestinal effects). The primary source of copper in drinking water is from corrosion of internal copper plumbing. The levels of copper in drinking water depend on the length of time the water has been stagnant in the copper piping, and thus, fully flushed water generally has low levels of copper. The levels of contamination can be increased near smelting facilities and phosphate fertilizer plants. In the study area, the concentration of copper ranged from nil to $0.33 \mathrm{mg} / \mathrm{l}$ (Table 3 ). The values were well within the permissible limits of EPA $(2 \mathrm{mg} / \mathrm{l})$.

3.2.2. Iron. Iron is an abundant metal found in earth's crust. It is naturally present in water but can also be present in drinking water from the use of iron coagulants or the corrosion of steel and cast iron pipes during water distribution. Iron is an essential element in human nutrition. The WHO [38] states that values of up to $2 \mathrm{mg} / \mathrm{l}$ (10 times the parametric value) do not present a hazard to health. However, at levels less than $2 \mathrm{mg} / \mathrm{l}$ but above the parametric value $(0.2 \mathrm{mg} / \mathrm{l})$, the colour of water may turn brown, become turbid, or may deposit solids on clothes washed in the water or food cooked using water. The concentration of iron in the tested samples varied from nil to $0.7 \mathrm{mg} / \mathrm{l}$ (Table 3). Based on this result, the iron levels for $38.46 \%$ of the water samples were above the parametric value given by EPA $(0.2 \mathrm{mg} / \mathrm{l})$, and iron levels for $23.07 \%$ of the samples were not within the permissible limits of the WHO and CES $(0.3 \mathrm{mg} /$ 1). A slightly higher concentration of iron may be attributed to the nature of the aquifer providing water [27]. Water with iron concentration greater than $0.3 \mathrm{mg} / \mathrm{l}$ might have a noticeable bad taste. Chronic iron overload results primarily from a genetic disorder (haemochromatosis) characterized by increased iron absorption and from diseases that require frequent transfusion [40].

3.3. Bacteriological Characteristics of the Water Samples. The term "faecal coliform" has been used in water microbiology to denote coliform organisms which grow at 44 or
TABLE 3: Copper and iron contents of the studied water samples of the study sites.

\begin{tabular}{lcc}
\hline Sampling points & Copper $(\mathrm{mg} / \mathrm{l})$ & Iron $(\mathrm{mg} / \mathrm{l})$ \\
\hline SW1 & 0.03 & 0.05 \\
SW2 & ND & 0.37 \\
SW3 & ND & 0.2 \\
SW4 & 0.02 & ND \\
SW5 & 0.32 & 0.3 \\
SW6 & 0.01 & 0.03 \\
SW7 & ND & 0.27 \\
SW8 & ND & 0.11 \\
DW1 & 0.33 & 0.27 \\
DW2 & 0.02 & 0.7 \\
DW3 & 0.1 & ND \\
DW4 & ND & 0.48 \\
DW5 & ND & 0.65 \\
DW6 & 0.01 & 0.4 \\
DW7 & 0.01 & ND \\
DW8 & 0.21 & ND \\
DW9 & ND & 0.33 \\
DW10 & ND & 0.28 \\
DW11 & 0.01 & 0.18 \\
DW12 & 0.001 & 0.15 \\
DS1 & 0.02 & 0.04 \\
DS2 & 0.01 & 0.03 \\
DS3 & 0.01 & 0.06 \\
DS4 & 0.002 & 0.02 \\
DS5 & 0.001 & 0.01 \\
DS6 & 0.01 & 0.03 \\
\hline ND & &
\end{tabular}

$\mathrm{ND}$, not detected.

$44.5^{\circ} \mathrm{C}$ and ferment lactose to produce acid and gas. In practice, some organisms with these characteristics may not be of faecal origin and the term "thermotolerant coliform" is, therefore, more correct and is becoming more commonly used. Nevertheless, the presence of thermotolerant coliforms nearly always indicates faecal contamination. Usually, more than $95 \%$ of thermotolerant coliforms isolated from water are the gut organism Escherichia coli, the presence of which is definitive proof of faecal contamination. As a result, it is often unnecessary to undertake further testing to confirm the specific presence of $E$. coli.

The total coliform count of the studied water samples was in the range from 0 (nil) to $200 \mathrm{cfu} / 100 \mathrm{ml}$ (Table 4). Only two water samples (SW1 and SW5) were detected free from thermotolerant colonies. Accordingly, $92.31 \%$ of the analyzed water samples were focally contaminated. The EPA, WHO, and Ethiopia water quality standard allowable thermotolerant count is $0 \mathrm{cfu} / 100 \mathrm{ml}$. Therefore, $92.31 \%$ of the studied water samples were out of this standard. According to IRC (2002) as cited by Michael [60] risk classification for thermotolerant coliforms of rural water supplies, nine water samples of the current study (DW1, DW2, DW4, DW6, DW7, DW8, DW9, DW10, and DW11) were classified under high risk (the thermotolerant count is in the range (101 to 1000)). Other water samples (SW2, SW3, SW6, SW7, SW8, DW3, DW5, DW12, DS3) were under intermediate risk (11 to 100), samples (SW4, DS1, DS2, DS4, DS5, DS6) were under low risk (1-10), and samples (SW1 and SW5) were categorized under no risk $(0 \mathrm{cfu} / 100 \mathrm{ml})$. In 
TABLE 4: The total coliform count of the studied water samples for the study sites.

\begin{tabular}{lc}
\hline Sampling points & Thermotolerant count \\
\hline SW1 & ND \\
SW2 & 25 \\
SW3 & 22 \\
SW4 & 10 \\
SW5 & ND \\
SW6 & 15 \\
SW7 & 20 \\
SW8 & 25 \\
DW1 & 200 \\
DW2 & 150 \\
DW3 & 100 \\
DW4 & 165 \\
DW5 & 12 \\
DW6 & 142 \\
DW7 & 185 \\
DW8 & 200 \\
DW9 & 160 \\
DW10 & 145 \\
DW11 & 140 \\
DW12 & 28 \\
DS1 & 6 \\
DS2 & 5 \\
DS3 & 12 \\
DS4 & 95 \\
DS5 & 756 \\
\hline & 7 \\
\hline
\end{tabular}

the study by Simon [41], 120 colonies of thermotolerant coliforms were found in the water sample taken from the well in Koga.

\section{Conclusion}

The turbidities of $100 \%$ of the studied water samples crossed the EPA limits of drinking water; the $\mathrm{pH}$ values for $23.08 \%$ of the analyzed water samples were not within the safe limit of standard set by the WHO and Ethiopian drinking water guidelines; the ammonia level of $100 \%$ of the studied samples violated the guideline set by EPA (may be due to agriculture fertilizers used in Koga irrigation found in the study area); the phosphate concentration of the studied water samples was above the phosphate regulations limit of EPA; and the iron level for $38.46 \%$ of the water samples had surpassed the parametric value given by EPA. The $\mathrm{PO}_{4}-\mathrm{P}(\mathrm{mg} / \mathrm{l})$ level of all analyzed water samples had exceeded the maximum acceptable level of $0.10 \mathrm{mg} / \mathrm{PO}_{4}-\mathrm{P}$ for prevention of eutrophication. This is an indication of significant anthropogenic inputs from domestic sewage, agricultural, and use of phosphate detergents. It follows that virtually all the water points in these regions are already under hypereutrophic state.

The total coliform number of most studied water samples (except sites SW1 and SW5) exceeded the upper limit set for drinking water bodies. This study concluded that the water sources of the study area are not safe for drinking unless appropriate treatment measurements are taken. The values for the water quality parameters for the water samples collected from Koga irrigation site were higher than the values for the water samples from the study sites found out of the irrigation site. This indicated the pollution load of Koga irrigation on the water quality of the area. The drinking water from the groundwater well was above the WHO standard for turbidity and well above the recommended bacteria levels. The water source is probably contaminated. Therefore, the municipal administration and service rendering sectors should provide the wastewater treatment in order to reduce the pollutants entering into the water points of the study areas. Further research should be conducted in the water points to investigate the detail water quality status of the areas by considering the seasonal/temporal variations of the water quality parameters throughout the year. Since, the current research is only limited to one season (dry season).

\section{Data Availability}

The data used to support the findings of this study are available from the corresponding author upon request.

\section{Conflicts of Interest}

The author declares that there are no conflicts of interest.

\section{References}

[1] J. Lane, "Invited editorial: the third world water forum," Water Policy, vol. 5, no. 4, pp. 381-382, 2003.

[2] U. U. Rehman, S. Khan, and S. Muhammad, "Associations of potentially toxic elements (PTEs) in drinking water and human biomarkers: a case study from five districts of Pakistan," Environmental Science and Pollution Research, vol. 25, no. 28, pp. 27912-27923, 2018.

[3] D. R. Boyd, The Water We Drink: An International Comparison of Drinking Water Quality Standards and Guidelines, David Suzuki Foundation, Vancouver, Canada, 2006.

[4] S. Muhammad, M. T. Shah, and S. Khan, "Health risk assessment of heavy metals and their source apportionment in drinking water of Kohistan region, northern Pakistan," Microchemical Journal, vol. 98, no. 2, pp. 334-343, 2011.

[5] P. Devorak, K. Roy, J. Andreji, Z. D. Liskova, and J. Mraz, "Vulnerability assessment of wild fish population to heavy metals in military training area: synthesis of a framework with example from Czech Republic," Ecological Indicators, vol. 110, p. 105920, 2020.

[6] H. Mano, F. Takeda, T. Kitamura et al., "Water quality comparison of secondary effluent and reclaimed water to ambient river water of southern Okinawa Island via biological evaluation," Environmental Monitoring and Assessment, vol. 189, no. 9, p. 442, 2017.

[7] J. Ciazela, M. Siepak, and P. Wojtowicz, "Tracking heavy metal contamination in a complex river-oxbow lake system: middle Odra valley, Germany/Poland," Science of the Total Environment, vol. 616-617, pp. 996-1006, 2018.

[8] S. Veerasingam, P. Vethamony, R. Mani Murali, and B. Fernandes, "Depositional record of trace metals and degree of contamination in core sediments from the Mandovi estuarine mangrove ecosystem, west coast of India," Marine Pollution Bulletin, vol. 91, no. 1, pp. 362-367, 2015. 
[9] L. I. Ezemonye, P. O. Adebayo, A. A. Enuneku, I. Tongo, and E. Ogbomida, "Potential health risk consequences of heavy metal concentrations in surface water, shrimp (Macrobrachium macrobrachion) and fish (Brycinus longipinnis) from Benin River, Nigeria," Toxicology Reports, vol. 6, pp. 1-9, 2019.

[10] S. S. Johannsen and P. Armitage, "Agricultural practice and the effects of agricultural land-use on water quality," Freshwater Forum, vol. 28, pp. 45-59, 2010.

[11] M. Javier and B. Jacob, Agricultural and Water Quality Interactions Global over View, pp. 25-43, Food and Agriculture Organization, Quebec City, Canada, 2011.

[12] WHO, Guidelines for Drinking Water Quality Third Edition Incorporating the First and Second Addenda Volume 1 Recommendations, pp. 123-567, WHO, Geneva, Sitzerland, 2008.

[13] S. Begum, M. T. Shah, S. Muhammad, and S. Khan, "Role of mafic and ultramafic rocks in drinking water quality and its potential health risk assessment, Northern Pakistan," Journal of water and health, vol. 13, pp. 1130-1142, 2015.

[14] N. W. Arnell, M. J. L. Livermore, S. Kovats et al., "Climate and socio-economic scenarios for global-scale climate change impacts assessments: characterising the SRES storylines," Global Environmental Change, vol. 14, no. 1, pp. 3-20, 2004.

[15] World Health Organization, The World Health Report: 2005: Make Every Mother and Child Count, World Health Organization, Geneva, Switzerland, 2005.

[16] M. Chan and A. Lake, "Towards ending preventable child deaths," The Lancet, vol. 379, no. 9832, pp. 2119-2120, 2012.

[17] L. Fewtrell, A. Pruss-Ustun, R. Bos, F. Gore, and J. Bartram, Water Sanitation and Hygiene: Quantifying the Health Impact at National and Local Levels in Countries with Incomplete Water Supply and Sanitation Coverage, World Health Organization, Geneva, Switzerland, 2007.

[18] H. Nasirian, S. Nazmara, A. H. Mahvi, M. Hosseini, L. Shiri, and B. Vazirianzadeh, "Assessment of some heavy metals in the Shadegan and Hawr Al Hawizea wetland waters from Iran," Indian Journal of Science and Technology, vol. 8, no. 1, pp. 1-9, 2015.

[19] S. Karim, A. Aouniti, M. Taleb et al., "Evaluation of heavy metal concentration in seven commercial marine fishes caught in the Mediterranean cost of Morocco and their associated health risks to consumers," Journal of Environment and Biotechnology Research, vol. 8, no. 1, pp. 1-13, 2019.

[20] H. Ali and E. Khan, "Bioaccumulation of $\mathrm{Cr}, \mathrm{Ni}, \mathrm{Cd}$ and $\mathrm{Pb}$ in the economically important freshwater fish Schizothorax plagiostomus from three rivers of Malakand division, Pakistan: risk assessment for human health," Bulletin of Environmental Contamination and Toxicology, vol. 102, no. 1, pp. 77-83, 2019.

[21] A. P. Annachhatre, "Water quality and waste water management," Environmental Management Tools: A Training Manual, pp. 125-129, Asian Institute of Technology, Bangkok, Thailand, 2006.

[22] E. Omer and T. Sallam, "Bacteriogical investigation of drinking water in Shendi Locality, River Nile State, Sudan," Open Access Scientific Reports, vol. 1, p. 329, 2012.

[23] P. Gwimbi, M. George, and M. Ramphalile, "Bacterial contamination of drinking water sources in rural villages of Mohale Basin, Lesotho: exposures through neighbourhood sanitation and hygiene practices," Environmental Health and Preventive Medicine, vol. 24, no. 1, p. 33, 2019.

[24] D. Amenu, S. Menkir, and T. Gobena, "Microbiological quality of drinking water sources in rural communities of Dire
Dawa Administrative Council," Science, Technology and Arts Research Journal, vol. 1, no. 4, pp. 33-37, 2012.

[25] A. Mengesha, M. Wubshet, and B. A. Gelaw, "Survey of bacteriological quality of drinking water in North Gondar," The Ethiopian Journal of Health Development (EJHD), vol. 18, no. 2, pp. 112-115, 2004.

[26] H. Amanial, "Assessment of physicochemical quality of spring water in Arbaminch, Ethiopia," Journal of Environmental Analytical Chemistry, vol. 2, pp. 2380-2391, 2015.

[27] D. A. Shigut, G. Liknew, D. D. Irge, and T. Ahmad, "Assessment of physico-chemical quality of borehole and spring water sources supplied to Robe Town, Oromia region, Ethiopia," Applied Water Science, vol. 7, no. 1, pp. 155-164, 2017.

[28] M. Yasin, T. Ketema, and K. Bacha, "Physico-chemical and bacteriological quality of drinking water of different sources, Jimma zone, Southwest Ethiopia,” BMC Research Notes, vol. 8, no. 1, p. 541, 2015.

[29] T. Alemayehu, Groundwater Occurrence in Ethiopia, Addis Ababa University, Addis Ababa, Ethiopia, 2006.

[30] A. W. Worako, "Physicochemical and biological water quality assessment of Lake Hawassa for multiple designated water uses," Journal of Urban and Environmental Engineering, vol. 9, no. 2, pp. 146-157, 2015.

[31] MWFEO (Mecha Woreda Finance and Economic Office), Summery Household Data, Mecha, Northwest Ethiopia, MWFEO (Mecha Woreda Finance and Economic Office), Amhara, Ethiopia, 2015.

[32] W. Bewket, "Rainfall variability and crop production in Ethiopia: case study in the Amhara region," in Proceedings of the 16th International Conference of Ethiopian Studies, vol. 3, pp. 823-836, Trondheim, Norway, July 2007.

[33] B. Alemayehu, F. Hagos, A. Haileslassie, E. Mapedza, S. B. Awulachew, and D. P. Tesfaye Tafesse, "Prospect of payments for environmental services in the blue Nile basin: examples from Koga and Gumera watersheds, Ethiopia," Improved Water and Land Management in the Ethiopian Highlands: Its Impact on Downstream Stakeholders Dependent on the Blue Nile, p. 254, IWMI Subregional Office for East Africa and Nile Basin, Addis Ababa, Ethiopia, 2009.

[34] MoWR (Ministry of Water Resources), "Koga irrigation and watershed management project: Koga small scale irrigation, rural water supply and sanitation," vol. 1, MoWR (Ministry of Water Resources), Addis Ababa, Ethiopia, 2005, Main Report.

[35] T. Mekonen and F. Kebede, "Suitability of Koga watershed for irrigated sugarcane and onion production in the blue nile basin, Ethiopia," Journal of the Dry Lands, vol. 4, no. 2, pp. 325-332, 2011.

[36] A. Wondimagegne and B. Tarekegn, "Levels of some trace metals in fishes tissues, water and sediment at Tendaho water reservoir, Afar region, Ethiopia," Journal of Aquaculture Research and Development, vol. 7, no. 1, p. 387, 2016.

[37] K. Gebremedhin and T. Berhanu, "Determination of some selected heavy metals in fish and water samples from Hawassa and Ziway Lakes," Science Journal of Analytical Chemistry, vol. 3, no. 1, pp. 10-16, 2015.

[38] WHO, Guidelines for Drinking Water Quality, WHO, vol. 1p. 515, 3rd edition, Geneva, Switzerland, 2004.

[39] J. Bartram and R. Balance, Water Quality Monitoring: A Practical Guide to the Design and Implementation of Freshwater Quality Studies and Monitoring Programmes, CRC Press, Boca Raton, FL, USA, 1996.

[40] WHO, Guideline for Drinking Water Quality, WHO, vol. 2p. 973, 2nd edition, Geneva, Switzerland, 1996. 
[41] E. Simon, Water Quality in the Koga Irrigation Project, Ethiopia: A Snapshot of General Quality Parameters, Uppsala University, Uppsala, Sweden, 2013.

[42] H. Åsa and L. Kristin, Effects on Drinking Water Quality due to Irrigation in the Koga Area of Merawi, Ethiopia, Uppsala University, Uppsala, Sweden, 2013.

[43] EPA, Microbiological, Chemical and Indicator Parameters in the 2014 Drinking Water Regulations 2014: An Overview of Parameters and Their Importance, Johns Town Castle Estate, Wexford, Ireland, 2014, http://www.epa.ie.

[44] WHO, Guidelines for Drinking-Water Quality, WHO, Geneva, Switzerland, 4th edition, 2011.

[45] B. A. Meseret, "Assessment of drinking water quality and determinants of household portable water consumption in Simada District, Ethiopia," M.Sc. Thesis, Cornell University, Ithaca, NY, USA, 2012.

[46] O. Gurmessa, Investigation of Drinking Water Quality from Source to Point of Distribution: The Case of Gimbi Twon in Oromia Regional State of Ethiopia, pp. 34-54, Addis Ababa Institute of Technology, Addis Ababa, Ethiopia, 2015.

[47] American Public Health Association, American Water Works Association, Water Pollution Control Federation, and Water Environment Federation, Standard Methods for the Examination of Water and Wastewater, Vol. 2, American Public Health Association, Washington, DC, USA, 1912.

[48] J. F. Talling, "Electrical conductance-a versatile guide in freshwater science," Freshwater Reviews, vol. 2, no. 1, pp. 65-78, 2009.

[49] World Health Organization, Guidelines for Drinking-Water Quality Second Edition Volume 3 Surveillance and Control of Community Supplies, p. 138, WHO, Geneva, Switzerland, 1997.

[50] I. P. Prosser, I. D. Rutherfurd, J. M. Olley, W. J. Young, P. J. Wallbrink, and C. J. Moran, "Large-scale patterns of erosion and sediment transport in river networks, with examples from Australia," Marine and Freshwater Research, vol. 52, no. 1, pp. 81-99, 2001.

[51] S. A. Muhammad, "An ecological study on the aquatic life of Sarchnar Spring, Chaq-Chaq and Kiliassan Streams, Sulaimani, Kurdistan Region of Iraq," M.Sc. Thesis, p. 142, College of Science, University of Sulaimani, Sulaymaniyah, Iraq, 2004.

[52] USEPA, Drinking Water Standards and Health Advisories, Office of Water, United States Environmental Protection Agency USEPA, Washington. DC, USA, 2004.

[53] A. Gebreyesus, "Physico chemical and microbiological analysis of potable surface and ground water samples in Dubti Amibara and Awash Fentale Woredas of Afar Region, Doctoral dissertation," Haramaya University, Dire Dawa, Ethiopia, 2013.

[54] L. A. Richards, "Diagnosis and improvement of saline and alkali soils," Soil Science, vol. 78, no. 2, p. 154, 1954.

[55] Compulsory Ethiopian Standard (CES), Drinking Water Specifications, Ethiopian Standards Agency, Addis Ababa, Ethiopia, 1st edition, 2013.

[56] J. Bartram and R. Ballance, Water Quality Monitoring: A Practical Guide to the Design and Implementation of Freshwater Quality Studies and Monitoring Programmes, CRC Press, Boca Raton, FL, USA, 1996.

[57] C. Clenaghan, F. Clinton, and M. Crowe, Phosphorus Regulations: National Implementation Report, 2005, Environmental Protection Agency, Dublin, Ireland, 2005.

[58] USGS NAWQA, http://water.usgs.gov/nawqa, September,
[59] WHO, pH in Drinking Water. Background Document for Development of WHO Guidelines for Drinking-Water Quality, WHO, Geneva, Switzerland, 2003.

[60] H. Michael, "Drinking-water quality assessment and treatment in East Timor. case study: tangkae," Engineering Thesis, The University of Western Australia, Perth, Australia, 2006. 